\title{
FACTORS ASSOCIATED WITH TREATMENT ADHERENCE AMONG PULMONARY TUBERCULOSIS PATIENTS IN MEULABOH, ACEH
}

\author{
Zakiyuddin, Ambia Nurdin
}

Faculty of Public Health, Universitas Teuku Umar, Meulaboh, Aceh

\begin{abstract}
Background: Tuberculosis (TB) remains a major global health problem, with at least three million deaths annually. Each year there are nearly 10 million new cases, of which four to five million are smear positive and, thus, highly contagious. This study aimed to analyze factors associated with adherence to TB treatment among pulmonary tuberculosis patients.

Subjects and Methods: A cross sectional study was carried out at Pahlawan Community Health Center, West Aceh. A sample of 40 TB patients were selected for this study by exhaustive sampling. The dependent variable was adherence to TB treatment. The independent variables were drug supervisor, knowledge, motivation, and familly support. TB status data were taken from medical record. The other data were collected by questionnaire. The data were analyzed by a multiple logistic regression.

Results: Adherence to TB treatment was associated with active drug supervisor $(\mathrm{OR}=3.38 ; \mathrm{p}=0.017)$, good knowledge $(\mathrm{OR}=2.64 ; \mathrm{p}=0.029)$, strong motivation $(\mathrm{OR}=4.48 ; \mathrm{p}=0.017)$, and strong family support $(\mathrm{OR}=3.11 ; \mathrm{p}=0.011)$.

Conclusion: Adherence to TB treatment is associated with active drug supervisor, good knowledge, strog motivation, and strong family support.
\end{abstract}

Keywords: TB treatment, adherence, drug supervisor, knowledge, motivation

\section{Correspondence:}

Zakiyuddin. Faculty of Public Health, Universitas Teuku Umar, Meulaboh, Aceh. Email: zakiyuddin@utu.ac.id. Mobile: +6281360060550. 